\title{
INVESTASI DAN DORONGAN PERTUMBUHAN EKONOMI BISNIS MIKRO ISLAM DI INDONESIA
}

\author{
Harun Santosa, Yudi Siyamto \\ STIE-AAS Surakarta
}

Email: harusnsantosa@yahoo.com

\begin{abstract}
The study aims to determine micro businesses in promoting growth of Islam in Indonesia. This research manifold qualitative research-based literature. Results from the study showed that micro businesses Islam is able to achieve 40 percent annually, much higher than conventional economic growth, which reached 19 percent annually in promoting economic growth in Indonesia.
\end{abstract}

Keywords: Investment, Islamic of Micro Business, Economic Growth

\section{PENDAHULUAN}

Berbagai cara ditempuh untuk menginvestasikan hartanya pada berbagai bidang kehidupan mulai dari baik investasi pada sektor riil maupun sektor non riil dengan tujuan mendapatkan keuntungan untuk menambah kekayaannya. Dalam ekonomi konvensional kapitalis, dalam hal bidang dan cara berinvestasi seseorang dapat dengan bebas melakukannya sepanjang ia dapat memperoleh keuntungan (return).

Saat ini invetasi non riil sangat berkembang dan cenderung lebih diminati masyarakat dari pada sektor riil. Hal ini disebabkan karena untuk berinvestasi disektor non riil seseorang tidak perlu harus memiliki modal ratusan juta, akan tetapi dengan modal kecil pun sesorang dapat berinvestasi.

Sedangkan berinvestasi di sektor riil seseorang diperlukan modal yang cukup besar dan resikonya pun cukup besar. Disamping itu masyarakat yang berinvestasi hanya melihat dari tren dan melihat bagaimana untuk memperoleh keuntungan semaksimal mungkin dan mudah. sehingga masyarakat tidak melihat apakah investasinya tersebut sesuai atau tidak menurut ajaran Islam. Salah satunya investasi non riil yang berkembang saat ini adalah melalui transaksi maya (virtual transaction) melalui transaksi derivatif yang penuh ribawi. Transaksi maya sangat dominan ketimbang transaksi riil. Transaksi maya mencapai lebih dari 95 persen dari seluruh transaksi dunia. Sementara transaksi di sektor riel berupa perdagngan barang dan jasa hanya sekitar lima persen saja. ${ }^{1}$

Kemiskinan merupakan masalah kronis yang melanda bangsa Indonesia. Banyak program pengentasan kemiskinan

http://aafandia.wordpress.com/2009/05/20/investa si-sektor-riil-dan-sektor-non-riil-dalam-perspektifekonomi-islam_bagian-1-2 (diakses tanggal $7 \mathrm{Mei}$ 2014) 
telah dilakukan, tetapi masih dirasakan belum banyak keberhasilannya, hasil yang dicapai tidak efisien dan tidak tepat sasaran. Di sisi lain, banyak yang belum mengerti bagaimana mengawali upaya penanggulangan kemiskinan tersebut. Berbagai forum, dari tingkat lokal maupun internasional, menggelar diskusi tentang kemiskinan yang intinya hanya satu, yaitu bagaimana membebaskan manusia dari belenggu kemiskinan. Salah satu upaya penanggulangan kemiskinan adalah dengan memutus mata rantai kemiskinan melalui pemberdayaan kelompok melalui pengembangan Microfinance, yaitu suatu model penyediaan jasa keuangan bagi masyarakat yang memiliki usaha pada sektor paling kecil yang tidak dapat mengakses bank karena berbagai keterbatasan. $^{2}$

Melihat kondisi sekarang di negara Indonesia jumlah penduduk miskinpun bertambah. Dimana Badan Pusat Statistik (BPS) mencatat jumlah penduduk miskin di Indonesia pada September 2013 mencapai 28,55 juta orang (11,47 persen) atau meningkat 0,48 juta orang dibandingkan dengan penduduk miskin pada Maret 2013 tercatat 28,07 juta orang (11,37 persen). Perinciannya, jumlah penduduk miskin di daerah perkotaan naik sebanyak 0,30 juta orang dari 10,33 juta orang pada Maret 2013 menjadi 10,63 juta orang pada September 2013. Selama periode Maret - September 2013, prosentase penduduk miskin di daerah perkotaan pada Maret 2013 sebesar 8,39 persen atau naik menjadi 8,52 persen pada

\footnotetext{
${ }^{2}$ Gunawan Sumodiningrat dalam bukunya Amalia, Eus, 2009, "Keadilan distributif dalam Ekonomi Islam”, hlm. 2
}

September 2013. Sementara, prosentase penduduk miskin di daerah perdesaan meningkat dari 14,32 persen pada Maret 2013 menjadi 14,42 persen pada September $2013 .^{3}$

Untuk menyelesaikan persoalan ekonomi bangsa Indonesia dalam upaya mengentaskan kemiskinan ini dapat dilakukan, antara lain dengan memutus mata rantai kemiskinan itu sendiri, diantaranya adalah dengan penguatan berbagai aspek di sektor Usaha Mikro, Kecil, dan Menengah (UMKM) yang pada dasarnya merupakan bagian dari masyarakat miskin yang mempunyai kemauan dan kemampuan produktif. ${ }^{4}$

Menteri Perencanaan Pembangunan Nasional/Kepala Bappenas, Armida Alisjahbana, mengatakan, Upaya mengentaskan kemiskinan kini sudah dilaksanakan Pemerintah melalui program nasional, yakni melakukan percepatan pertumbuhan ekonomi dan pembangunan sektor ril. Untuk pertumbuhan ekonomi, Menteri mengatakan, tentunya ekonomi yang dimaksud adalah perekonomian yang menciptakan kesempatan kerja dan ekonomi makro. Dalam hal ini kita mulai mengubah paradigma, bahwa UMKM adalah kegiatan yang menjadi penopang pembangunan ekonomi. Oleh karenanya pembinaan sektor hulu UMKM harus ditingkatkan, terutama akses perbankan bagi sektor hulu tersebut," kata menteri. ${ }^{5}$

\footnotetext{
${ }^{3}$ Jumat, 03 Januari 2014, 02:10 WIB, Replubika, http://www.republika.co.id/berita/nasional/umum/ 14/01/03/mysfdt-jumlah-penduduk-miskinindonesia-bertambah (di akses tanggal $20 \mathrm{Mei}$ 2014)

${ }^{4}$ Wijono, "Keadilan....", hlm. 7

${ }^{5}$ Minggu, 24 Oktober 2010, 07:07 WIB, Replubika, http://www.republika.co.id/berita/breaking-
} 
UMKM adalah pelaku usaha dengan jumlah yang sangat besar, bahkan mayoritas dalam struktur pelaku usaha di tanah air. Hal ini dapat dilihat dari sumber Bappenas, bahwa data Usaha Kecil Mikro pada tahun 2007 adalah sebanyak 41.30 juta unit $(99,85 \%)$, usaha menengah 61,05 juta unit $(0,14 \%)$, dan usaha besar 2,2 juta unit $(0,005 \%)$. Dari jumlah tersebut, dampaknya pada penyerapan tenaga kerja, sumbangan terhadap PDB, nilai ekspor nonmigas, dan nilai investasi tidak dapat dianggap kecil. Berturut-turut berada pada angka sekitar 85,4 juta orang (96,2\% dari tenaga kerja nasional), Rp 110,3 triliun (20,3\% dari ekspornas), dan Rp 369,8 triliun (46,2\% dari investasi nasional). ${ }^{6}$

Jika dilihat dari pertumbuhan UMKM ternyata mampu menumbuhkan perekonomian hingga pada sektor kecil. Dalam hal ini merupakan Upaya pemerintah dalam penanggulangan kemiskinan dan pengangguran yang merupakan program yang harus diupayakan oleh pemerintah dalam pemberdayaan ekonomi rakyat. Peran penting keberadaan UMKM di Indonesia semakin terasa dalam proses pembangunan nasional Indonesia. Pada awal keberadaan UMKM dianggap sumber penting dalam penciptaan kesempatan kerja dan motor penggerak utama pembangunan ekonomi pedesaan. Namun, pada era globalisasi saat ini dan mendatang, peran keberadaan UMKM semakin penting yakni sebagai salah satu

news/ekonomi/10/10/24/142090-pemberdayaanumkm-solusi-atasi-kemiskinan, Diakses Tanggal $20 \mathrm{Mei} 2014$

${ }^{6}$ BPS, Pendapatan Nasional Indonesia 2003-

2006, dalam bukunya Amalia, Eus, 2009,

"Keadilan distributif dalam Ekonomi Islam", hlm. 10 sumber devisa non-migas Indonesia, (Tambunan, 2002). ${ }^{7}$

Oleh karena itu, penenlitian ini membahas Bagaiamana dorongan pertumbuhan Ekonomi Bisnis Mikro Islam jika dilihat dari peran UMKM pada LKMS dalam memajukan pertumbuhan ekonomi di Indonesia.

\section{INVESTASI DALAM PANDANGAN KONVENSIONAL DAN ISLAM}

Investasi secara garis besar adalah menanamkan atau menempatkan aset, baik berupa harta maupun dana, pada sesuatu yang diharapkan akan memberikan hasil pendapatan atau akan meningkatkan nilainya di masa mendatang.

Berbagai macam investasi dapat dilakukan dalam berbagai bidang kehidupan manusia, mulai dari yang sangat sederhana sampai investasi yang sangat rumit dan memerlukan pengetahuan khusus. Namun secara umum investasi dapat dibagi menjadi dua bagian besar, yaitu:

1. Investasi di Sektor Riil (Real Asset). Investasi di produk yang lebih terlihat secara "fisik", misalkan sektor produksi, property, dan lain-lain.

2. Investasi di Sektor Non Riil (Financial Asset). Investasi di produk-produk pasar keuangan dan turunannya yang lebih "tidak terlihat" secara fisik, misalkan saham biasa dan obligasi. Dengan kata lain investasi non riil atau investasi keuangan adalah menanamkan dana pada surat berharga

\footnotetext{
${ }^{7}$ P. Eko Prasetyo, 2008, "Peran Usaha Kecil dan Menengah (UMKM) dalam Kebijakan Penanggulangan Kemiskinan dan Pengangguran”.
} 
(financial asset) yang diharapkan akan meningkat nilainya di masa mendatang.

Investasi merupakan kegiatan yang sangat dianjurkan, karena dengan berinvestasi harta yang dimiliki menjadi produktif dan juga mendatangkan manfaat bagi orang lain. Investasi pula adalah cara yang sangat baik agar harta itu dapat berputar tidak hanya dalam segelintir orang saja. Dengan Investasi, maka akan mendorong distribusi pendapatan yang baik pada masyarakat. Namun demikian investasi sebagai kegiatan ekonomi haruslah berdasarkan kepada prinsipprinsip hukum muamalah, yaitu: ${ }^{8}$

1. Pada dasarnya segala bentuk muamalat adalah boleh kecuali yang dilarang oleh nash.

2. Menetapkan kebolehan tidak perlu mencari dasar hukum syara'.

3. Nash tidak dimaksudkan sebagai pembatasan.

4. Menciptakan bentuk muamalah baru tidak perlu mencari padannya (qiyas) dalam nash.

5. Menetapkan kebolehan tidak perlu menganalogkan atau mentakhrij hasil ijtihad para ulama

6. Tidak melanggar nash yang mengharamkan.

7. Muamalat dilakukan atas pertimbangan maslahah

8. Muamalat dilaksanakan untuk memelihara nilai keadilan.

Dalam hal hubungan antara investasi dan tabungan, faktor penting yang

http://aafandia.wordpress.com/2009/05/20/investas i-sektor-riil-dan-sektor-non-riil-dalam-perspektifekonomi-islam_bagian-3/ (diakses tanggal 7 Mei 2014) menjadi pembeda antara sistem keuangan konvensial dan sistem keuangan syariah adalah bunga. Dalam konvensional hubungan investasi dan tabungan dihubungkan oleh peran bunga dalam perekonomian. Sehingga bunga menjadi indikator fluktuasi yang terjadi di investasi dan tabungan. Ketika bunga (bunga simpanan dan bunga pinjaman) tinggi maka kecenderungan tabungan akan meningkat, sementara investasi relatif turun. Begitu sebaliknya, ketika bunga rendah, maka tabungan akan menurun dan investasi akan meningkat. Dengan demikian dapat dikatakan bahwa motivasi dalam aktivitas tabungan dan investasi dalam konvensional didominasi oleh motif keuntungan (returns) yang bisa didapatkan dari keduanya. Sedangkan dalam dalam perekonomian islam sistem bunga tidak ada. Sebagai penggantinya adalah sistem bagi hasil (profit and loss sharing). Dengan demikian maka hubungan investasi dan tabungan dalam perekonomian Islam tidak sekuat seperti yang ada dalam konvensional.

Investasi sektor rill dalam islam pada dasarnya adalah boleh selama berpedoman pada prinsip-prinsip muamalat islam, yaitu: $^{9}$

1. Pada dasarnya segala bentuk muamalat adalah boleh kecuali yang dilarang oleh nash.

2. Muamalat dilakukan atas pertimbangan maslahah

3. Muamalat dilaksanakan untuk memelihara nilai keadilan.

\footnotetext{
${ }^{9}$ http://aafandia.wordpress.com/2009/05/20/investa si-sektor-riil-dan-sektor-non-riil-dalam-perspektifekonomi-islam_bagian-7/ (diakses tanggal 7 Mei 2014)
} 
Diantara skema investasi yang bisa dilakukan dalam islam adalah investasi pada perusahaan yang melakukan transaksi jual beli (al-bai'), jual beli barter (al-muqayadhah), jual beli mutlak, jual beli mata uang (sharf), jual beli pesanan (al-salam), jual beli istishna', jual beli Murabahah, jual beli Tauliyah, jual beli Wadi'ah, jual beli Musawamah, sewa menyewa (ijaroh), kerjasama dalam perdagangan (syirkah), mudharabah, dan kerjasama dalam bidang pertanian (muzara'ah dan musaqah).

Adapun jenis investasi riil yang dilarang melihat dari barang yang diproduksinya adalah seperti investasi pada perusahaan pembuatan alkohol, perjudi, perusahaan senjata gelap, jual beli barang najis dan bisnis pornografi. Sedangkan jenis investasi riil yang dilarang melihat dari cara pelaksanaanya adalah seperti :

1. Jual beli sesuatu yang tidak ada (bai' al-ma'dum).

2. Menjual barang yang tidak dapat diserahkan pada pembeli (bai'u ma'zuji al-taslim).

3. Jual beli 'arabun/'urbun adalah menjual suatu barang dengan lebih dulu membayar panjar kepada pihak penjual (sebelum benda yang dibeli diterima), dengan ketentuan jika jual beli jadi dilaksanakan, uang panjar itu dihitung sebagai bagian dan harga, dan jika pihak pembeli mengundurkan diri maka uang panjar itu menjadi milik pihak penjual.

Bentuk-Bentuk Investasi Sektor Non Rill Menurut Ekonomi Islam

1. Perbankan Syariah

Nasabah yang menabung di bank syariah tidak akan diberikan keuntungan bunga melainkan berupa bagi hasil.

2. Asuransi Syariah

Pada asuransi syariah, perjanjiannya adalah para nasabah mengikatkan diri dalam suatu komunitas dan saling menanggung jika terjadi musibah dan diawasi oleh Dewan Pengawas Syariah yang, memastikan bahwa semua mekanisme asuransi dan alokasi investasinya tidak bertentangan dengan hukum syariah.

3. Sekuritas syariah

Yang dimaksud dengan skuritas syariah adalah efek yakni sebuah nama kolektif untuk macammacam surat berharga yaitu berupa :

a. Saham syariah

Tidak semua saham yang terdaftar di pasar modal memenuhi prinsipprinsip syarih. Untuk itu Bursa Efek Jakarta bekerjsama dengan Dana reksa Investemen Management, mengembangkankan suatu indeks untuk melisting saham-saham mana saja yang layak dianggap memenuhi prinsip-prinsip syariah. Indeks ini disebut dengan Jakarta Islamic Indeks (JII).

b. Obligasi Syariah

Obligasi syariah adalah suatu surat berharga berjangka panjang berdasarkan prinsip syariah yang dikeluarkan emiten kepada pemegang obligasi syariah yang mewajibkan emiten untuk membayar pendapatan kepada pemegang obligasi syariah berupa bagi hasil/margin/fee serta membayar kembali dana obligasi pada saat jatuh tempo. 
Jenis obligasi syariah jika dilihat dari aspek akad sangat beraneka ragam yaitu obligasi salam, obligasi istina, obligasi murabahah, ijarabah, dan obligasi musyarakah. Akan tetapi yang terkenal dan diminati masyarakat adalah obligasi mudharabah dan ijarah.

c. Reksa Dana Syariah

Pada reksa dana syariah, keputusan investasi yang dilakukan oleh manajer investasi dilakukan dalarn batasan-batasan rambu syariah. Dengan cara ini, hasil investasi yang dibagikan kepada para investor menjadi bersih dari riba dan unsur yang tidak halal lainnya.

\section{PERAN LEMBAGA KEUANGAN MIKRO (LKM) DALAM AKSES PERMODALAN UKM}

Dalam mengembangkan LKM untuk malayani masyarakat miskin (economically active poor) yang pada umumnya tinggal di desa-desa tersebut, terdapat alternatif yang dapat dilakukan mengingat keterbatasan yang dimiliki terkait dengan sistem yang digunakan, adapun alternatif yang dapat digunakan adalah sebagai berikut:

\section{Banking of the poor}

Yaitu mobilisasi keuangan mendasarkan diri dari kemampuan yang dimiliki masyarakat miskin itu sendiri. Lemabaga ini seperti swadaya masyarakat (KSM), kelompok usaha bersama (KUBE), Credit union (CU), Kooperasi Simpan Pinjam (KSP), dll.

\section{Banking with the poor}

Adalah hubungan bank dengan suatu lembaga binaan dalam meraih nasabah. Lembaga ini secara keseluruhan dibina oleh bank yang melayani pembiayaan besar.

3. Banking for the poor

Bentuk ini mendasarkan diri atas credit led institution, di mana sumber dari financial support terutama bukan diperoleh dari mobilisasi tabungan masyarakat miskin, namun diperoleh dari sumber lain yang memang ditujukan untuk masyarakat miskin. Contoh bentuk ini adalah Badan Kredit Desa (BKD), Lembaga Dana Kredit Perdesaan (LDKD), Grameen Bank, ASA, Dll. ${ }^{10}$ 
Kebijakan Usaha Kecil Mikro (UKM) dan Lembaga Keuangan Mikro (LKM) Dalam konteks Indonesia, kriteria usaha penting dibedakan untuk penentuan kebijakan yang terkait. Skala usaha $:^{11}$ dibedakan menjadi usaha mikro, kecil, menengah, dan usaha besar. Adapun ragam pengertian UMKM menurut beberapa lembaga dan peneliti adalah sebagai berikut

\begin{tabular}{|c|c|c|}
\hline Lembaga & Istilah & Batasan Pengertian Secara Umum \\
\hline $\begin{array}{l}\text { UU No. 9/95 } \\
\text { (Usaha Kecil) }\end{array}$ & Usaha Kecil & $\begin{array}{l}\text { Aset } \leq \mathrm{Rp} 200 \text { juta luar tanah dan bangunan } \\
\text { atau omset } \leq \mathrm{Rp} 1 \text { milyar per tahun }\end{array}$ \\
\hline $\begin{array}{l}\text { INPRES } \\
\text { No.10/1999 }\end{array}$ & $\begin{array}{l}\text { Usaha } \\
\text { Menengah }\end{array}$ & $\begin{array}{l}\text { Memiliki kekayaan bersih } \mathrm{Rp} 200 \text { juta }-\mathrm{Rp} 10 \\
\text { milyat (tidak termasuk tanah dan bangunan } \\
\text { tempat usaha) }\end{array}$ \\
\hline \multirow[t]{3}{*}{$\begin{array}{l}\text { Badan Pusat } \\
\text { Statistik (BPS) }\end{array}$} & Usaha mikro & $\begin{array}{l}\text { Pekerja }<5 \text { orang termasuk tenaga kerja } \\
\text { keluarga }\end{array}$ \\
\hline & Usaha kecil & Pekerja $5-9$ orang \\
\hline & $\begin{array}{l}\text { Usaha } \\
\text { menengah }\end{array}$ & Pekerja $20-99$ orang \\
\hline \multirow{3}{*}{$\begin{array}{l}\text { Menteri Negara } \\
\text { Koperasi dan } \\
\text { UKM }\end{array}$} & Usaha kecil & Aset $<200$ juta di luar tanah dan bangunan \\
\hline & & \\
\hline & $\begin{array}{l}\text { Usaha } \\
\text { menengah }\end{array}$ & $\begin{array}{l}\text { Aset }>200 \text { juta atau omset Rp } 1-10 \text { milyar per } \\
\text { tahun }\end{array}$ \\
\hline \multirow[t]{3}{*}{$\begin{array}{ll}\text { Bank } & \text { Indonesia } \\
\text { (BI) } & \end{array}$} & Usaha Mikro & $\begin{array}{l}\text { dijalankan oleh rakyat miskin atau dekat } \\
\text { miskin, bersifat usaha keluarga, menggunakan } \\
\text { sumber daya lokal, menerapkan teknologi } \\
\text { sederhana dan mudah keluar masuk industri. }\end{array}$ \\
\hline & Usaha Kecil & Aset $<$ Rp 200 juta atau omset Rp 1 Milyar. \\
\hline & $\begin{array}{l}\text { Usaha } \\
\text { Menengah }\end{array}$ & $\begin{array}{l}\text { Untuk kegiatan industri, aset }<\text { Rp } 5 \text { Milyar, } \\
\text { untuk lainnya (termasuk jasa), Aset }<\text { Rp } 600 \\
\text { juta diluar tanah dan bangunan atau omset }<\text { Rp } \\
3 \text { Milyar per tahun. }\end{array}$ \\
\hline \multirow[t]{3}{*}{ Bank Dunia } & Usaha Mikro & $\begin{array}{l}\text { Pekerja }<10 \text { orang, Aset }<\$ 100.000 \text { atau } \\
\text { Omset }<\$ 100.000 \text { per tahun }\end{array}$ \\
\hline & Usaha Kecil & $\begin{array}{l}\text { Pekerja }<50 \text { orang, Aset }<\$ 3 \text { juta atau omset } \\
<\$ 3 \text { juta per tahun }\end{array}$ \\
\hline & $\begin{array}{l}\text { Usaha } \\
\text { Menengah }\end{array}$ & $\begin{array}{l}\text { Pekerja }<300 \text { Orang, Aset }<\$ 15 \text { juta, omset }< \\
\$ 15 \text { juta per tahun. }\end{array}$ \\
\hline
\end{tabular}

${ }^{11}$ Krisnamurti, (dalam Yustika, 2005), Ibid P. Eko Prasetyo, 2008, 
Pendekatan yang dipakai dalam rangka pengentasan kemiskinan tentu berbeda-beda yaitu terbagi menjadi tiga kelompok. Kelompok pertama akan lebih tepat jika digunakan pendekatan langsung berupa program pangan, subsidi, atau penciptaan lapangan kerja, sedangkan bagi kelompok kedua dan ketiga, lebih efektif jika digunakan pendekatan tidak langsung, misalnya penciptaan iklim yang konduksif bagi pengembangan UKM, pengembangan berbagai jenis pinjaman mikro atau mensinergikan UKM dengan para pelaku Usaha Menengah maupun besar. Berikut merupakan struktur LKM (microfinance) di Indonesia: ${ }^{12}$

$$
\text { Aspek Historis Kebijakan }
$$

Pengembangan Usaha Kecil Mikro (UKM) di Indonesia dalam pengembangan UKM sudah dilakukan di masa Orde Baru akan tetapi hingga saat sekarang belum optimal dalam realisasi. Permasalahan yang muncul pada saat itu kemudian terjawab dengan adanya kredit Investasi Kecil (KIK) dan Kredit Modal Kerja Permanen (KMKP). Respon terhadap program ini cukup besar karena suku bungan murah $(\mathrm{KIK}=10,5 \%$ dan $\mathrm{KMKP}=12 \%$ per tahun). Suku bunga itu lebih rendah atau paling tidak sama dengan BIMAS untuk petani miskin yang besarnya $1 \%$ per bulan, juga lebih rendah dari pada kredit pensiunan yang besarnya $18 \%$ per tahun. Dan juga persyaratannya teknis perbankan mudah, jaminan lebih diutamakan pada kegiatan usahanya (project colleteral) dan memenuhi kriteria layak. ${ }^{13}$ Pada saat ini program ini dapat

\footnotetext{
${ }^{12}$ Opcit, Saat Suharso dalam bukunya Amalia, Eus, 2009. Hlm. 54

${ }^{13}$ Ibid, hlm. 60-61
}

diakatakan seperti Kredit Usaha Rakyat (KUR) dimana pada program ini merupakan program yang sangat membantu pertumbuhan ekonomi masyarakat kecil karena tidak memberatkan oleh rakyat dalam melakukan pembiayaan.

Perkembangan perbankan syariah di Indonesia di ikuti dengan perkembangan lembaga-lembaga keuangan nonbank lainnya dapat dikatakan mengalami pertumbuhan yang bagus untuk kedepan dalam menumbuhkan pertumbuhan ekonomi. Program linkage antara bank syariah dengan LKMS, dalam hal ini BPRS dan BMT, bahkan dikembangkan pula sinergitasnya dengan lembagalembaga sosial seperti institusi zakat dan wakaf untuk menopang perluasan sektor riil dan UKM. Saat ini, jumlah BMT di Indonesia mencapai lebih dari 3.038 buah menurut PINBUK. Sebagai lembaga keuangan berbasis syariah, BMT di Indonesia berprospek tumbuh karena didukung oleh potensi sumber daya manusia, dimana mayoritas penduduknya adalah beragama Islam, dan mampu menyelaraskan gerak roda perekonomian umat terutama ekonomi mikro. ${ }^{14}$

Sejarah perkembangan BMT dimulai pada era 1980-an hingga sekarang ini, statistik yang akurat tentang BMT memang belum tersedia. Menurut perkiraan Pusat Inkubasi Bisnis Usaha Kecil (PINBUK), sampai pertengahan tahun 2006, terdapat sekitar 3.200 BMT yang beroperasi di Indonesia. Anggota dan calon anggota yang dilayani waktu itu mencapai 3 juta orang. PINBUK memproyeksikan jumlahnya akan

${ }^{14}$ Ibid, hlm. 81 
meningkat menjadi 10 juta pada tahun 2010, yang akan dilayani oleh banyak BMT lagi, yang diperkirakan bertambah 1.000 - 2.000 BMT per tahun sampai dengan tahun tersebut. ${ }^{15}$

Hingga akhir 2012 ini, sudah ada 3.900 BMT. Sebanyak 206 di antaranya bergabung dalam asosiasi BMT seluruh Indonesia," ujar Joelarso saat ditemui di Universitas Gadjah Mada, Yogyakarta, di sela-sela BMT Summit 2012, Rabu, 7 November 2012. Pada 2005, ia menambahkan, seluruh aset 96 BMT yang menjadi anggota asosiasi mencapai $\mathrm{Rp}$ 364 miliar. Pada 2006, aset tumbuh menjadi Rp 458 miliar, dan hingga akhir 2011 jumlah aset mencapai Rp 3,6 triliun dari 206 BMT yang bergabung di asosiasi. BMT tersebut berada di Jawa Tengah, Yogyakarta, Jawa Barat, Jawa Timur, Jakarta, Bali, Kalimantan Barat, Lampung, dan Sulawesi Tenggara. ${ }^{16}$

\section{METODOLOGI PENELITIAN}

Penelitian ini menggunakan penelitian studi pustaka, berupa mengadakan penelitian dengan cara mempelajari dan membaca literaturliteratur yang memiliki hubungan dengan permasalahan-permasalahan yang menjadi obyek dalam penelitian. Adapun yang diteliti pada penelitian ini adalah teks-teks yang akan memberikan gambaran pada kriteria-kriteria pekerja yang handal. Penelitian ini juga termasuk juga penelitian yang bersifat deskriptif. Sehingga penelitian ini bertujuan

${ }^{15} \mathrm{Ibid}, \mathrm{hlm} .90$

${ }^{16}$ Rabu, 07 November 2012 | 13:53 WIB, http://www.tempo.co/read/news/2012/11/07/08944 0268/Aset-BMT-Tumbuh-Signifikan (di akses tanggal 29 mei 2014) membuat deskripsi mengenai situasisituasi atau kejadian-kejadian. ${ }^{17}$

\section{LEMBAGA KEUANGAN MIKRO SYARIAH (LKMS) BAGI PENGUATAN USAHA KECIL MIKRO (UKM)}

Dari hasil penelitian yang telah dilakukan oleh Euis Amalia dimana survei yang dilakukan di Tangerang, Depok, Jakarta Selatan, Jakarta Barat, Jakarta Timur, Wonosobo, dan Yogyakarta sebanyak 25 Unit BMT dengan Informan sebanyak 48 manajer dan sebagai pengelola BMT serta juga kepada nasabah sebanyak 511 orang. Selain itu juga dilakukan wawancara mendalam dengan para ketua asosiasi lembaga pembina BMT antara lain: PINBUK, ABSINDO, BMT Center, BMT Permodalan, Baitulmal Muamalat, dan Mumalat Center Indonesia. $^{18}$

Karateristik LKMS dari hasil penelitian dimana secara deskriptif untuk berdasarkan Asset yang dimiliki adalah berdasarkan kisaran < 500 juta ada 5 BMT, antara 500 juta s/d 1 Milyar ada 1 BMT, 1 milyar s/d 5 Milyar ada 12 BMT, 10 s/d 20 ada 1 BMT, dan yang > 20 Milyar ada 3 BMT. ${ }^{19}$ Sedangkan peran lembaga keuangan jika dilihat dari nasabah dalam memenuhi kebutuhan mendesak saat tidak memiliki dana sendiri dengan hasil LKMT/BMT sebesar 73,2\% sebagai solusi, tetapi ada juga yang memanfaatkan sumber pinjaman lainnya yaitu keluarga/kerabat $30,7 \%$, teman $28,4 \%$,

\footnotetext{
${ }^{17}$ Supardi. 2005. "Metodologi Penelitian Ekonomi Bisnis". Yogyakarta: UII Press.

${ }^{18}$ Opcit, Saat Suharso dalam bukunya Amalia, Eus, 2009. Hlm. 143

${ }^{19} \mathrm{Ibid}, \mathrm{hlm} .146$
} 
koperasi konvensional 4,7\%, rentenir $4,1 \%$, pegadaian $2,7 \%$, Bank Umum Syariah 1,2\%, BPR konvensional 0,6\%. Tingginya pilihan kepada BMT adalah karena nasabah pada umumnya adalah rasionalis dan pragmatis, artinya pilihannya bukan hanya atas dasar syariah tetapi memiliki sumber pinjaman yang cepat dan memenuhi kebutuhan jangka pendek. Jika dilihat dari sumber permodalan UKM untuk pengembangan Usaha LKMS/BMT merupakan sumber permodalan yaitu sebesar $87,7 \%$. selain itu, mereka juga menggunakan lembaga lainnya seperti koperasi 4,5\%, Bank Umum Syariah, Bank Konvensional 3,3\%, BPRS 1,8\%, BPR konvensional 0,4\%, dan keuangan lainya $0,4 \% .^{20}$

Dari hasil penelitian diatas dapat diketahui bahwasanya masyarakat pada umumnya sangat membutuhkan dana untuk keperluan kehidupannya baik untuk konsumtif maupun produktif. Pada sekilas hasil penelitian tersebut bahwasanya masyarakat lebih condong terhadap LKMS/BMT baik untuk pinjaman maupun penambahan modal karena kebanykan masyarakat kecil umumnya dalam memilih pinjaman maupun penambahan modal lebih tertarik pada lembaga keuangan dengan syarat yang mudah dan tidak ribet. Meskipun dari hasil penelitian ini tingkat pengetahuan masyarakat terhadap syariah masih dianggap kurang. Akan tetapi, dengan munculnya lembaga ini diharapkan dapat menumbuhkan perekonomian dari sektor kecil. Maka perlunya sebuah lembaga mikro dalam penumbuhan ekonomi dari segi permasalahan yang dihadapai sekaligus potensi yang dihadapi dapat dijelaskan dalam tabel dibawah ini:

\footnotetext{
${ }^{20}$ Ibid, hlm. 159 


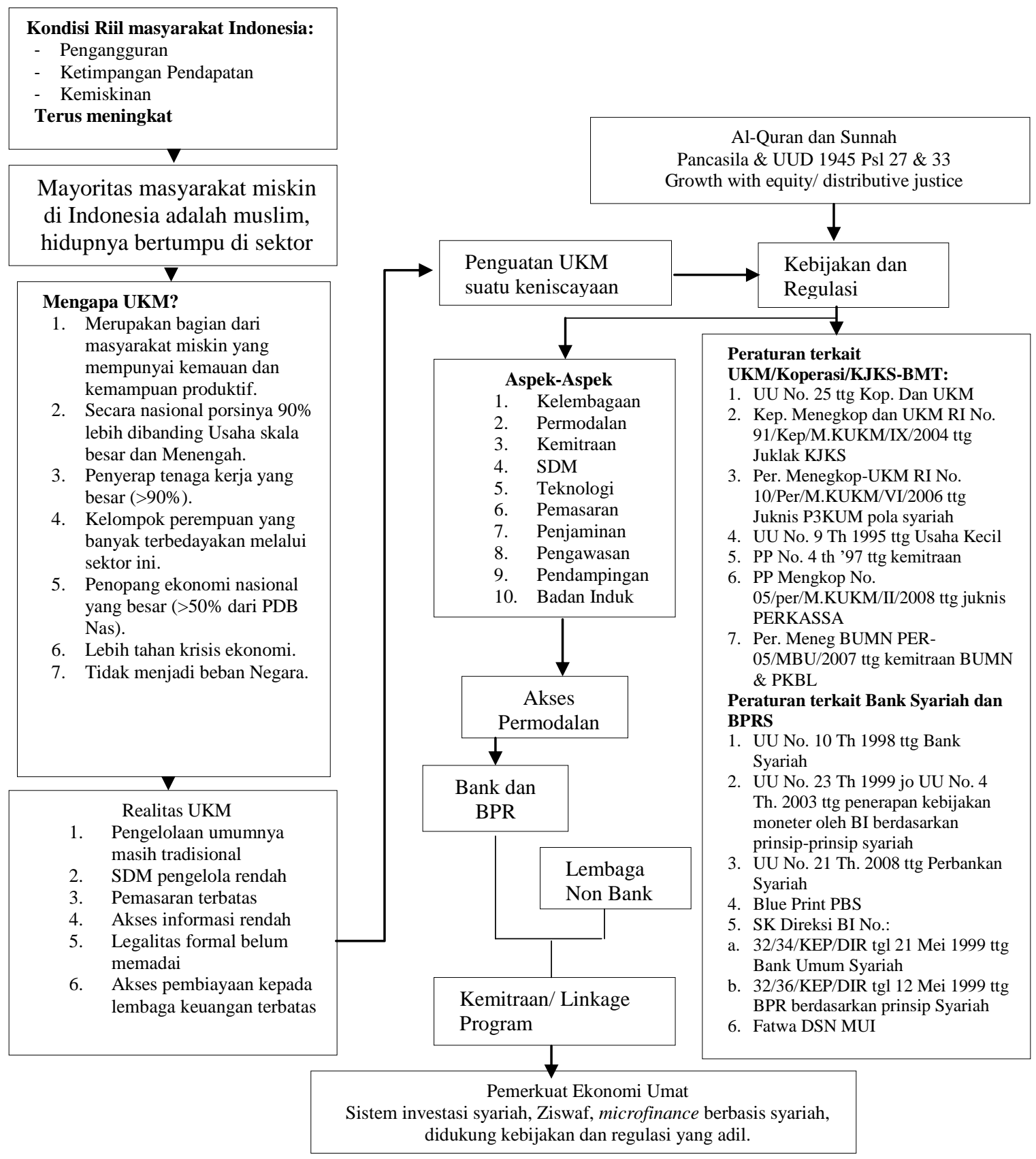




\section{PERTUMBUHAN DARI \\ DITINJAU

DARI \\ PERBANKAN \\ TERHADAP \\ UMKM \\ SYARIAH MENGURANGI KEMISKINAN DI INDONESIA}

Bank Indonesia (BI) menilai, meski pertumbuhan industri perbankan nasional terus mengalami perbaikan, namun kontribusinya dalam pembangunan ekonomi nasional masih sub-optimal alias belum memadai. Hal yang berlawanan itu terlihat pada fakta bahwa rasio total aset industri perbankan terhadap produk domestik bruto (PDB) Indonesia pada September 2011 beberapa taun yang lalu lalu hanya sebesar 47,2\%.Di sisi lain, rasio penyaluran kredit terhadap PDB hanya 29\%. Sebagai perbandingan, rasio kredit terhadap PDB di Malaysia 114\%, Thailand 117\%, dan Cina 131\%.Selain itu, perspektif dari dunia usaha memberi gambaran yang sama, seperti hasil survei BI yang menyebutkan bahwa pangsa kredit bank dari total pembiayaan perusahaan sangat minim, yaitu untuk modal kerja (KMK) hanya $25 \%$ dan untuk investasi (KI) hanya $21 \%$.

Sebaliknya, dana internal perusahaan (self financing) tersebut merupakan sumber utama pembiayaan perusahaan, yaitu $61 \%$ untuk investasi dan $48 \%$ untuk modal kerja.Tingginya aset industri perbankan yang belum seimbang dengan peningkatan kontribusinya terhadap perekonomian nasional terjadi karena aset perbankan yang dari perspektif makro tidak produktif, yaitu penempatan dalam instrumen moneter dan surat berharga negara (SBN). Kepemilikan bank pada SBN adalah Rp 245,97 triliun, sementara dana bank pada instrumen moneter di SBI dan term deposit Rp 415,48 triliun. Total penempatan ini mencapai $31,4 \%$ dari total kredit yang mencapai Rp 2.106,2 triliun. Sekitar $60 \%$ dari penempatan dana bank di instrumen moneter BI dikuasai oleh 10

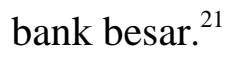

Pengentasan kemiskinan dengan cara mengembangkan UMKM memiliki potensi yang cukup baik. Sektor UMKM memiliki kontribusi yang besar bagi penyerapan tenaga kerja, yaitu menyerap lebih dari 99,45\% tenaga kerja. Meskipun demikian kontribusinya terhadap PDB masih sekitar 30\%. Upaya untuk memajukan sektor UKMK tentu saja akan dapat meningkatkan kesejahteraan para pekerja yang terlibat di dalamnya. Pengembangan UMKM akan dapat menyerap lebih banyak lagi tenaga kerja yang ada sehingga dapat mengurangi angka pengangguran.

Sektor UMKM sendiri memiliki prospek yang menjanjikan. Kucuran kredit perbankan di sektor ini tahun 2004 mencapai Rp 72,3 triliun atau naik sebesar $187,1 \%$ dibandingkan rencana anggaran sebesar Rp 38,5 triliun. Upaya pemerintah untuk menyediakan kredit mikro bagi pengembangan UKM sebagai upaya pengentasan kemiskinan merupakan upaya yang baik. Sebagai sektor utama penyerapan tenaga kerja, kemajuan UMKM akan memberikan dampak yang

21

https://www.academia.edu/6035584/Peluang_dan_ Tantangan_Prospek_Perbankan_2014 
signifikan bagi peningkatan kesejahteraan masyarakat yang terlibat di dalamnya, sehingga jumlah penduduk miskin akan menurun.

Bukti lain dari peranan strategis sektor Usaha Mikro, Kecil dan Menengah (UMKM) yakni kemampuan sektor ini menjadi pilar utama ekonomi Indonesia. Berdasarkan data Badan Pusat Statistik (BPS) 2005, jumlah UMKM mencapai 42,39 juta unit atau sekitar $99,85 \%$ dari total unit usaha di Indonesia dan mampu menyerap lebih kurang 99,45\% lapangan kerja dari total sekitar 76,54 juta pekerja (Krisna Wijaya, Kompas, Senin 22 Agustus 2005, hal 21). Selain itu, sektor UMKM juga mampu menyediakan sekitar 57\% kebutuhan barang dan jasa, 19\% kontribusinya terhadap ekspor serta kontribusi terhadap pertumbuhan ekonomi nasional mencapai $2-4 \% .{ }^{22}$ Berikut data peran UMKM dalam menciptakan lapangan kerja dan Penciptaan Devisa Nasional: ${ }^{23}$

Mengutip data Bank Indonesia, hingga akhir 2012 terdapat 11 Bank Umum Syariah (BUS), 24 Bank Syariah dalam bentuk Unit Usaha Syariah (UUS), dan 156 BPRS dengan jaringan kantor sebanyak 2.574 lokasi atau tumbuh sebesar 25,31\%.

Pembiayaan perbankan syariah hingga akhir 2012 menunjukkan peningkatan pada pembiayaan modal kerja

\footnotetext{
${ }^{22}$ Supriyanto, "Pemberdayaan Usaha Mikro, Kecil, Dan Menengah (Umkm) Sebagai Salah Satu Upaya Penanggulangan Kemiskinan", Jurnal Ekonomi \& Pendidikan, Volume 3 Nomor 1, April 2006

${ }^{23} \mathrm{http}: / /$ www.scribd.com/doc/17398234/StatistikUMKM-2009
}

usaha yang mayoritas atau sekitar $60 \%$ disalurkan pada usaha mikro dan kecil. Hingga bulan Juni 2013 sebesar 75.98\% dari portofolio pembiayaan perbankan syariah menggunakan akad Murabahah. Sementara pembiayaan berbasis akad Mudharabah-Musyarakah berkontribusi $2.96 \%$ dari total portofolio perbankan syariah.

Selain itu, perkembangan lembaga keuangan mikro syariah baik bank dan non bank menunjukkan kinerja yang menggembirakan dengan rata-rata pertumbuhan di kisaran $30 \%$ baik pembiayaan maupun berdasrakan asetnya. Misalnya rata-rata pertumbuhan asset BPR Syariah selama 6 tahun terakhir (Januari 2008 - Juni 2013) mencapai $30.49 \%$ dan rata-rata pertumbuhan pembiayaan yang disalurkan kepada masyarakat mencapi $31.52 \%$.

Dilihat dari orientasi penggunaan pembiayaan, mayoritas pembiayaan yang disalurkan BPR Syariah didominasi oleh pembiayaan untuk modal kerja lebih $50 \%$ dibandingkan pembiayaan untuk konsumsi (35\%) atau investasi (10\%). Pertumbuhan pembiayaan untuk investasi menunjukkan angka lebih tinggi dibandingkan dengan pertumbuhan pembiayaan untuk konsumsi maupun modal kerja,

Sementara jika dilihat berdasarkan skala usaha dan sektor usaha debitur, mayoritas debitur BPR Syariah adalah usaha skala mikro, kecil, dan menengah. Hingga Juni 2013 sebanyak 58.93\% dari portofolio pembiayaan BPR Syariah adalah pembiayaan untuk debitur UMKM 
dan sisanya adalah pembiayaan untuk debitur non-UMKM.

Adapun pembiayaan yang disalurkan oleh BPR Syariah mayoritas untuk debitur-debitur yang berada di sektor lainlain $(36.72 \%)$ dan sektor perdagangan, restoran, dan hotel (33.82\%). Sektorsektor produktif seperti pertanian hanya memiliki presentase sebesar $8.95 \%$, jauh lebih rendah dibandingkan sektor perdagangan, restoran, dan hotel dan sektor lain-lain. $^{24}$

\section{KESIMPULAN}

Dari hasil pembahasan di atas dapat diambil kesimpulan dorongan pertumbuhan Ekonomi Bisnis Mikro Islam jika dilihat dari peran UMKM pada LKMS dalam memajukan pertumbuhan ekonomi di Indonesia sangat memiliki peran yang aktif, dimana kebanyakan masyarakat kecil membutuhkan dana dalam penambahan modal usaha. Hal ini didorong pertumbuhan pada sektor kecil sangat dominan dalam mengentaskan kemiskinan karena masyarakat dapat memenuhi kebutuhan keseharianya dan juga dapat mengurangi pengangguran. Jadi jelas bahwa UMKM di Indonesia dapat dikatakan memiliki peran yang sangat penting.

Perkembangan ekonomi berbasis syariah di tanah air sungguh luar biasa, yaitu mencapai 40 persen setiap tahunnya, jauh lebih tinggi dibanding pertumbuhan ekonomi konvensional yang hanya mencapai 19 persen setiap tahunnya.

\footnotetext{
${ }^{24}$ www.setkab.go.id/berita-11096-janganpandang-enteng-pertumbuhan-ekonomi-syariah-diindonesia.html
}

Sehingga Kontribusi nyata ekonomi syariah dalam proses pembangunan nasional menjadi kekuatan untuk terus mendorong pertumbuhan ekonomi syariah di Indonesia. Dengan mendorong perkembangan ekonomi syariah, inklusivitas pembangunan dapat terus kita tingkatkan sekaligus mempercepat proses pemerataan pembangunan, mereduksi kesenjangan baik antar penduduk maupun antar wilayah, mengentaskan kemiskinan dan membantu sistem jaringan pengaman sosial yang selama ini telah berjalan.

\section{DAFTAR PUSTAKA}

Amalia, Eus, 2009, "Keadilan distributif dalam Ekonomi Islam", PT. Raja Grafindo Persada. Jakarta.

P. Eko Prasetyo, 2008, "Peran Usaha Kecil dan Menengah (UMKM) dalam Kebijakan Penanggulangan Kemiskinan dan Pengangguran”. Akmenika UPY, Volume 2.

Supardi. 2005. "Metodologi Penelitian Ekonomi Bisnis". Yogyakarta: UII Press.

Supriyanto, "Pemberdayaan Usaha Mikro, Kecil, Dan Menengah (Umkm) Sebagai Salah Satu Upaya Penanggulangan Kemiskinan", Jurnal Ekonomi \& Pendidikan, Volume 3 Nomor $\quad 1, \quad$ April 2006http://aafandia.wordpress.com/2 009/05/20/investasi-sektor-riil-dansektor-non-riil-dalam-perspektifekonomi-islam_bagian-1-2 (diakses tanggal 7 Mei 2014)

http://aafandia.wordpress.com/2009/05/2

O/investasi-sektor-riil-dan-sektornon-riil-dalam-perspektif-ekonomi- 
islam_bagian-3/ (diakses tanggal 7 Mei 2014)

http://aafandia.wordpress.com/2009/05/2

O/investasi-sektor-riil-dan-sektornon-riil-dalam-perspektif-ekonomiislam_bagian-7/ (diakses tanggal 7 Mei 2014)

https://www.academia.edu/6035584/Pelua ng_dan_Tantangan_Prospek_Perban kan_2014 (Di akses tanggal 10 Juli 2014)

http://www.republika.co.id/berita/breakin g-news/ekonomi/10/10/24/142090pemberdayaan-umkm-solusi-atasikemiskinan, Diakses Tanggal $20 \mathrm{Mei}$ 2014 http://www.republika.co.id/berita/nasiona l/umum/14/01/03/mysfdt-jumlahpenduduk-miskin-indonesiabertambah (di akses tanggal 20 Mei 2014)

http://www.scribd.com/doc/17398234/Stat istik-UMKM-2009 (Di akses tanggal 10 Juli 2014)

http://www.tempo.co/read/news/2012/11/0 7/089440268/Aset-BMT-TumbuhSignifikan (di akses tanggal 29 mei 2014)

www.setkab.go.id/berita-11096-janganpandang-enteng-pertumbuhanekonomi-syariah-di-indonesia.html (Di akses tanggal 10 Juli 2014) 